ISA

Arboriculture \& Urban Forestry 2017. 43(1):15-26

\title{
Tools for Staging and Managing Emerald Ash Borer in the Urban Forest
}

\author{
Clifford S. Sadof, Gabriel P. Hughes, Adam R. Witte, Donnie J. Peterson, \\ and Matthew D. Ginzel
}

\begin{abstract}
Advances in control can help municipal foresters save ash trees from emerald ash borer (EAB) [Agrilus planipennis (Fairmaire)] in urban forests. Although ash trees of any size can be protected from this pest, cities often do not implement programs because they fail to recognize and act on incipient populations of EAB. In this study, researchers develop a model for predicting ash mortality over an eight-year period, and validated with data from the removal of $>14,000$ ash trees killed by EAB in Fort Wayne, Indiana, U.S. researchers then developed a sampling scheme to help foresters map their ash trees along the expected progression of ash decline. This model was then used to modify a web-based EAB cost calculator that compares discounted annual and cumulative costs of implementing a variety of management strategies. It was determined that strategies that most heavily relied on saving ash trees were less expensive and produced a larger forest than those strategies that mostly removed and replaced ash trees. Ratios of total discounted costs to discounted cumulative benefits of strategies that saved most ash trees were over two-thirds lower than strategies of proactive tree removal and replacement. Delaying implementation of an ash management program until damage would be visible and more obvious to the community (Year 5 of the model) decreased the cost-benefit ratio by $<5 \%$. Thus, delays that rely on the abundance of locally damaged trees to bolster community support do not necessarily diminish the utility of implementing a control strategy.

Key Words. Agrilus planipennis; Ash; Ash Tree Decline Model; EAB Cost Calculator; Emerald Ash Borer; Indiana; Pest Management; Projection.
\end{abstract}

Since its detection in Detroit, Michigan, U.S., in 2002, emerald ash borer (EAB), [Agrilus planipennis (Fairmaire)] has spread to 25 states and two Canadian provinces, killing hundreds of millions of ash trees in its wake (Emeraldashborer.info 2015). EAB attacks and kills most North American ash species. Adult beetles lay eggs on the tree bark. Neonate larvae bore into the phloem tissue, and as they develop, consume greater amounts of active xylem tissue of this ring-porous tree species. Beetles take one to two years to complete their life cycle, and with repeated attack, they can functionally girdle and kill their host trees (Cappaert et al. 2005; Wei et al. 2007; Tluczek et al. 2011). With the exception of blue ash, Fraxinus quadrangulata (Tanis and McCullough 2012; Tanis and McCullough 2015), all healthy North American species of Fraxinus can experience high rates of mortality from this pest. With over eight billion ash trees in North America, the potential for continued devastation will likely make
EAB the most destructive pest to invade the forests of this continent (Herms and McCullough 2014).

Ash trees contribute significantly to the canopy of urban forests, with 38 million trees estimated to be present in eastern North America (Kovacs et al. 2010). While ash species account for between $20 \%$ and $30 \%$ of the urban forest in many cities, it is not uncommon for cities in some regions of the United States (e.g., Colorado and Iowa) to have an ash component of $>50 \%$ (Raupp et al. 2006; Ball et al. 2007; Sydnor et al. 2007; Sydnor et al. 2011). Thus, the spread of EAB threatens a substantial portion of the urban forest and will cost North American cities well over USD $\$ 10$ billion to manage (Kovacs et al. 2010; McKenny et al. 2012). The availability of highly effective insecticides has now made it possible to protect trees from EAB with applications of a variety of active ingredients even after damage has reduced canopy density by $50 \%$ (Herms et al. 2014). In practice, however, few trees with $>30 \%$ 
canopy thinning are selected to be saved due to a potential loss of structural integrity and aesthetic value after the damaged portion has been removed. Protection provided by a single insecticide application ranges from one to four years and depends on tree size, compound, dose, and solubility of the insecticide formulation. Of these products, a single injection of emamectin benzoate is highly toxic to adult $\mathrm{EAB}$ and larvae and can protect ash trees for two to three years (Smitley et al. 2010; McCullough et al. 2011; Flower et al. 2015; Poland et al. 2015). Ongoing studies indicate that even large trees (dbh $>120 \mathrm{~cm}$ ) can be protected (CSS, MDG pers. obs.).

The spread of EAB and its damage through a forest has been described using a wave analogy (Burr and McCullough 2014). At the cusp of the wave, during the first few years after detection, the density of $\mathrm{EAB}$ is low $\left(<10 / \mathrm{m}^{2}\right)$ and mortality rates of EAB larvae in trees are high (Chen et al. 2012; MacQuarrie and Scharback 2015). During this phase, most ash trees appear healthy and are largely asymptomatic. As densities of larvae increase, the added stress diminishes the capacity of trees to defend themselves, and larval mortality rates decline (Villari et al. 2016). Populations of EAB then begin to grow exponentially as the invasion wave swells to its crest. During the crest phase, enough phloem has been consumed to cause most of the ash trees to express symptoms of canopy thinning (Anulewicz et al. 2007). After EAB has consumed most of the available ash phloem, local EAB populations begin to decline as beetles disperse in search of more suitable ash hosts. Strategies that have been proposed to slow the spread of $\mathrm{EAB}$ and its wave of destruction in a forest rely on applying consistent protective measures soon after its detection in an area during the cusp phase of the invasion (Kovacs et al. 2011; McCullough and Mercader 2012; McCullough et al. 2015).

Recent cost-benefit analyses indicate that protecting healthy trees from EAB with insecticides can be more cost-effective than simply removing trees as they die and replanting with resistant trees. Investigations that seek to optimize the net present value of past funds spent on tree maintenance and ecosystem services provided by trees, suggest that cities should focus management efforts on trees with a dbh of at least $30 \mathrm{~cm}$ (Kovacs et al. 2010). Attempts to optimize limited monetary resources available for managing trees in a metro- politan area suggest that most of the funds be allocated to protecting trees, and that resources should be pooled across political boundaries to allow cities to benefit from the economy of scale (Kovacs et al. 2014). Several interactive web-based tools have been developed to allow users to customize local cost estimates for both individual trees (McKenny and Pedlar 2012) and urban forests (Vannatta et al. 2012), and the output from these models suggest a similar course of action. Despite this emerging consensus on the utility of protecting ash trees, many municipalities still believe the costs to protect trees are prohibitive, and elect to replace trees after they are killed by EAB.

Clearly, there is a gap in knowledge between the course of action suggested by recent theoretical advances and the practice of EAB management. In this study, researchers characterize how cities currently experiencing $\mathrm{EAB}$ outbreaks are managing their ash resource to test the assumption that few cities are opting to protect substantial numbers of trees. The following describes how researchers modified the web-based EAB Cost Calculator (Sadof et al. 2011) with a model to better predict long- and short-term costs of various management strategies at specific stages of the invasion wave. Finally, representative cost estimates are used to predict total discounted costs and forest size resulting from different management strategies implemented before and after damage from EAB is likely to be detected. The goal is to outline a process for systematically assessing the stage of an EAB invasion, and predicting management costs to inform the decision-making process of cities with substantial numbers of ash trees.

\section{MATERIALS AND METHODS}

\section{Assessing Current Municipal Man- agement Practices for EAB}

On 04 March 2014, a Google ${ }^{\text {tx }}$ web search was conducted to determine the number of cities whose EAB programs were highlighted in the news during the preceding 12-month period. The search was conducted using the following key terms: emerald ash borer city protect, or emerald ash borer city management. Management practices were placed into five categories that describe the extent to which cities chose to protect rather than remove trees (Table 1). 
Table 1. Strategies employed by municipalities to manage emerald ash borer and their rationales in cities found in a web search covering a 12-month period ending 04 March 2014.

\begin{tabular}{lll}
\hline Strategy & Rationale & $\begin{array}{l}\text { Percentage of } \\
\text { cities }(\mathrm{n}=40)\end{array}$ \\
\hline Reactively remove ash & Remove dying ash to prevent hazard & 20.0 \\
Proactively removing all ash & Removing ash over time to reduce annual cost & 17.5 \\
Protecting only legacy ash & $\begin{array}{l}\text { Only healthy trees of historic or significant } \\
\text { landscape importance are protected }\end{array}$ & 5.0 \\
Protecting $<50 \%$ of healthy ash & $\begin{array}{l}\text { A substantial proportion beyond legacy ash } \\
\text { trees are protected }\end{array}$ & 40.0 \\
Protecting $>50 \%$ of healthy ash & Most of the healthy ash are protected & 17.5 \\
\hline
\end{tabular}

\section{Estimating Large- and Small-Scale Treatment Costs}

In order to better understand the variation in costs associated with emamectin benzoate treatments, researchers sought to determine if there was a relationship between the cost of application and the number of trees treated. From September through December 2014, information was gathered from public records on the prices paid per $2.54 \mathrm{~cm}$ dbh to treat municipal ash trees in 27 municipalities in Indiana, Illinois, Missouri, Minnesota, and Ohio, U.S. Researchers also gathered information on the number of trees in each bid and then assessed the relationship between the actual bid price for an emamectin benzoate treatment and the number of trees.

\section{Development and Validation of a Model of Ash Forest Decline}

Researchers developed a model (Figure 1) that used percentages of ash mortality to predict the accumulated number of ash trees to be removed because they were in poor condition (i.e., losing more than $30 \%$ of their canopy to $\mathrm{EAB}$ ). The default settings of the calculator assumed the city was early in the cusp phase of the invasion wave, with $1 \%$ of ash trees in the poor category. Each year the percentage of affected ash trees doubled, so that by the fifth year, it reached $16 \%$, or approximately one out of six ash trees. The percentage peaked in year eight, with $100 \%$ of the trees characterized as being in poor condition. In the last three years of the model, $84 \%$ of the trees reached this level of decline. This pattern of ash destruction is premised on a hypothetical rise and fall of the maximum EAB population that responds to the available ash resource (Figure 1).
Researchers tested the ability of the model to predict ash tree decline in two ways. First the decline of untreated urban ash trees was compared, from 2010 through 2015, in Lafayette, Indiana, U.S., where EAB was first detected in 2011, and on the north side of Indianapolis, Indiana, where EAB was detected in 2006. In each city, approximately 100 ash trees with a dbh between 14 to $40 \mathrm{~cm}$ were selected. Each summer, 50 ash trees were visually assessed as good ( $<10 \%$ canopy decline) and 50 were ranked as fair $(10 \%$ to $<30 \%$ canopy decline) (Hughes et al. 2015). Trees were ranked as poor if they had more than $30 \%$ canopy thinning, and those in the critical category exceeded $>80 \%$ canopy thinning. The capacity of the model to predict

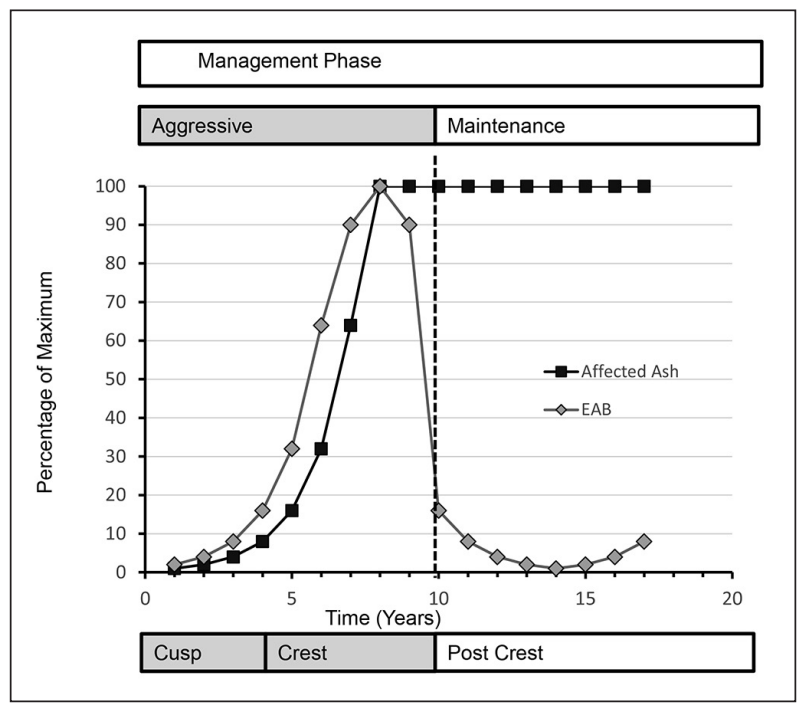

Figure 1. An invasion wave model to predict borer density and the decline of ash trees and guide management intensity in different stages of the initial invasion of the emerald ash borer. Affected ash trees represent those trees that are too damaged to be saved ( $>30 \%$ canopy thinning) with an insecticide treatment. 
rates of ash decline in each forest at each survey date was determined by comparing observed and predicted numbers of ash trees entering at least the poor category with a Kolmogorov-Smirnov test (Gotelli and Ellison 2004). This method was also used to determine the ability of the model to predict the number of ash trees removed in a city during the initial EAB invasion. Here, predicted values were compared with actual removals for the City of Fort Wayne, Indiana, from the first year EAB was detected (2006) through the year when the last of the 14,403 untreated ash trees were removed (2013).

\section{Modification of a Web-Based Cost Calculator}

The modified EAB Cost Calculator (Sadof 2016) is based on a previous version (Sadof et al. 2011) that used a local inventory of ash trees and local estimates of pricing for treatment, removal, and replacement of trees based on tree size. Users can choose predefined strategies or create their own strategy that chooses the percentage of trees in each size class that will be removed, replaced, or protected with insecticides. Annual and cumulative costs of up to three management strategies are plotted for 25 years. Benefits of each management strategy are compared by plotting the expected total dbh of all surviving ash trees resulting from each management strategy. To account for the time value of money, the modified calculator uses the same formula as in the first version to calculate the present value of costs (Rose et al. 1988).

The local tree inventory is used to create a matrix of trees that is applied in an iterative approach to simulate annual tree growth and costs for 25 years. Trees within each size class are assigned equally spaced starting sizes that are approximated by dividing the span width by the number of trees in a size class. So, if there are 600 trees in the $15-30 \mathrm{~cm}$ category, the calculator creates a matrix of 600 trees with sizes $0.024 \mathrm{~cm}$ apart. Annual growth of surviving trees is approximated by a linear model that adds $1.143 \mathrm{~cm}$ of dbh per year based on a linear estimate of growth quantified for ash trees (Peper et al. 2014). When trees are "killed" by EAB or through planned removal, the model randomly selects individuals in each size class that will be removed and replaced. Two additional $15 \mathrm{~cm}$ growth spans are built into the model to receive trees that grow beyond the last size class provided by the original tree inventory.
Cities whose trees have already begun to show damage can stage their infestation from the percentage of ash trees in the poor category and start the simulation at a more relevant point in the eight-year ash forest decline model. The EAB Cost Calculator allows cities to start as late as six-years into the invasion. By the seventh year of the cycle, when $64 \%$ of the trees are beyond saving, ash management options are restricted to removal and replacement. During this phase, the model's predictions are not likely to be accurate because it cannot predict the distribution of live trees left to treat.

Municipal arborists can adjust the frequency of pesticide applications to be most aggressive during the cusp and crest phases of the invasion as EAB populations are building and threatening tree heath. After 10 years, two years after all untreated trees are rendered beyond saving, there is little ash phloem to support the beetles. As such, populations of $\mathrm{EAB}$ are presumed to be present, but at a much lower level. For this reason, the EAB Cost Calculator switches from an aggressive to a maintenance phase of management after this time (Figure 1). Operationally, in the aggressive phase, all trees designated for protection are treated frequently enough to provide maximum protection. In the post-crest phase, pesticide applications are replaced by an integrated pest management approach that includes monitoring annually for fresh symptoms of EAB attack, such as woodpeckers or bark splits. Detection of these symptoms triggers a round of insecticide application, before substantial, additional canopy thinning occurs. Reduced costs are approximated in the model by reducing the frequency of pesticide application in this maintenance phase.

\section{Defining Management Strategies}

A fictitious forest, composed of 1,600 ash trees, was used to estimate management costs and forest growth over time (Table 2). The size class of this forest was skewed toward larger trees to account for fewer ash trees being planted after EAB was detected in 2002. Approximately two thirds of the ash trees in this forest had a dbh $>30 \mathrm{~cm}$. The costs of six common management strategies (Table 3) represent a range of management combinations of tree removal, replacement, and treatment with insecticides. 
It was assumed that all trees treated in this simulation would be treated with emamectin benzoate once every three years during the aggressive management phase and once every five years in the maintenance phase. Researchers assumed that over the 25 -year period, only $2 \%$ of the ash trees treated with this pesticide would die due to insecticide failure because of the high efficacy of this product (Herms et al. 2014). Trees dying due to insecticide failure were removed and replaced. Researchers chose the commonly used mortality rate of $5 \%$ to estimate loss of replacement trees due to transplant failure (McPherson et al. 2006). An annual mortality rate of $2 \%$ was applied to all trees to approximate normal loss. The cost to plant, stake, and mulch a new 3.2 $\mathrm{cm}$ dbh tree was set to $\$ 400$. Rates approved for the City of Indianapolis in December 2014 were used to estimate the costs of removing a tree and grinding the stump (Table 2). A 3\% discount rate was used to estimate the present value of costs.

Table 2. Size class distribution of ash forest and cost (\$USD per $\mathrm{cm} \mathrm{dbh)} \mathrm{to} \mathrm{remove} \mathrm{and} \mathrm{grind} \mathrm{the} \mathrm{stump} \mathrm{of}$ an ash tree of each size used in the model simulation. Costs were based on rates for the City of Indianapolis, Indiana, U.S., in 2014.

\begin{tabular}{lll}
\hline $\begin{array}{l}\text { Size span } \\
(\mathrm{cm} \mathrm{dbh})\end{array}$ & $\begin{array}{l}\text { Ash trees } \\
\text { in forest }\end{array}$ & $\begin{array}{l}\text { Removal and } \\
\text { grinding cost }\end{array}$ \\
\hline $3-8$ & 50 & $\$ 14.00$ \\
$8-15$ & 200 & $\$ 14.00$ \\
$15-30$ & 300 & $\$ 14.75$ \\
$30-46$ & 400 & $\$ 18.00$ \\
$46-61$ & 300 & $\$ 21.75$ \\
$61-76$ & 200 & $\$ 25.10$ \\
$76-91$ & 100 & $\$ 30.50$ \\
$>91$ & 50 & $\$ 36.00$ \\
\hline
\end{tabular}

\section{COSTS AND BENEFITS OF MAN- AGEMENT PROGRAMS}

Researchers ran simulations early and late in the wave of ash decline in order to predict discounted costs from a current inventory and assessment of tree quality 25 years into the future. The simulation of an early intervention began during the first year of the ash-decline wave when EAB would be difficult to detect with only one percent of the trees exhibiting the obvious symptom of losing $>30 \%$ of their canopy. This is the scenario of a city that would be able to initiate a program before symptomatic trees were apparent in a community. Simulation of a late intervention was conducted during the fifth year of the ash-decline wave, when the presence of EAB would be easy to detect with $16 \%$ of trees expressing obvious symptoms. Here, the same inventory of trees in Table 2 were used, but with the infestation staged at Year 5 in order compress the time available for the city to remove dying trees. Both the early and late simulations were conducted using a cost of \$3.94/ $\mathrm{cm} \mathrm{dbh}$ to represent the cost for treating low numbers of trees, and at $\$ 1.94 / \mathrm{cm}$ dbh to represent discounts given for bulk purchase of treatment services.

Necessary adjustments were made to some of the EAB Cost Calculator outputs in order to compare costs incurred when initiating a management program either early or late in the ash-decline wave. The early simulation, starting in Year 1, provided an accurate estimate of the present value of costs and tree growth throughout the 25-year cycle of each management scenario in an urban forest. For the late simulation, researchers assumed no added cost for EAB management during the first

Table 3. Management strategies used to compare costs and benefits in the EAB Cost Calculator 3.0 simulation. See text for more details about how costs were calculated.

\begin{tabular}{ll}
\hline Management strategy & Detail \\
\hline $\begin{array}{l}\text { Proactively replace ash } \\
\text { Reactively replace ash }\end{array}$ & $\begin{array}{l}\text { Proactively remove and replace all ash trees before EAB has damaged them beyond the point of rescue. } \\
\text { Remove and replace ash trees as the model of ash decline predicts that emerald ash borer will damage them beyond the point } \\
\text { of rescue. }\end{array}$ \\
Save $50 \%$ & $\begin{array}{l}\text { Treat half of the ash trees with insecticide and proactively remove and replace the rest. } \\
\text { Save } 80 \%\end{array}$ \\
$\begin{array}{l}\text { Treat } 80 \% \text { of the ash trees with insecticide and proactively remove and replace the rest. } \\
\text { Treat ash trees with insecticides when } \mathrm{cbh}>30 \mathrm{~cm} \text {. Remove and replace the rest. This strategy optimizes previous municipal } \\
\text { investment in larger trees and the benefits of ecosystem services they provide (Kovacs et al. 2010). }\end{array}$ \\
Treat all & All ash trees are protected by insecticide treatment. \\
\hline
\end{tabular}


four years and started projecting costs in Year 5 when $16 \%$ of ash trees were damaged beyond saving and thus removed. The size of the standing ash forest during these first four years was approximated using the size of treated ash trees calculated for the early simulation. In this way, the starting size of the forest in the late simulation could account for the modest growth and limited removal of trees that would occur before implementing an EAB management plan. This limited removal early in the invasion wave would compress tree removal costs in Years 5-8 of the simulation.

Benefits of each management plan were presented in two ways: First, the forest size was tracked and plotted as trees grew over 25 years under each management regime for the earlyand late-intervention scenarios. These plots can be useful for managers who make decisions based on forest size. Second, researchers measured the sum of the total tree dbh discounted annually at $3 \%$ over the 25 years for the early and late scenarios. This summation represents the accumulated discounted benefits of each management strategy over time in terms of discounted total tree diameters. The total discounted costs and accumulated discounted benefits were used to calculate a cost-benefit ratio that was expressed in dollars $/ \mathrm{m} \mathrm{dbh}$.

\section{RESULTS}

\section{Assessing Current Municipal Man- agement Practices for EAB}

Of the 40 cities encountered in the web search, $37.5 \%$ elected to remove rather than save any ash trees. Five percent of cities chose to save only ash trees of historic or landscape importance, whereas $40 \%$ of cities saved less than half their ash trees. Articles that provided reasons for lack of treatment used words like: lack of guarantee, high price, lack of confidence that product will save trees, trees are already too damaged. Only $17.5 \%$ of cities chose to save more than half of their healthy ash trees (Table 1).

\section{Estimating Large- and Small-Scale Treatment Costs}

Of the 27 cities contacted for this study, 12 used emamectin benzoate to treat their trees (Figure 2).
Six cities with bids that included $<150$ trees paid an average of $\$ 3.29+0.56 / \mathrm{cm}$ dbh to have a contractor treat the trees. Six cities with $>150$ trees in their bid paid an average of $\$ 1.82+0.09 / \mathrm{cm}$ $\mathrm{dbh}$ to have trees treated. This average bid was 44.7\% lower than bids to treat less than 150 trees.

\section{Validation of Ash-Decline Model}

The ash-decline model accurately predicted the annual number of ash trees removed from Fort Wayne, Indiana, in five out of eight years (Figure $3 \mathrm{a})$ (K-S $=0.0136, P<0.01$ ). In contrast, the model accurately predicted the decline of those trees ranked as good or fair condition to poor in all but one year of monitoring efforts in Lafayette $(\mathrm{K}-\mathrm{S}=0.146$, $P<0.01)$ and Indianapolis (K-S $=0.156, P<$ 0.01 ) (Figure 3b; Figure 3c). Higher rates of ash tree decline in 2012 may have been due to the historic drought that occurred during that year in the Lafayette and Indianapolis area.

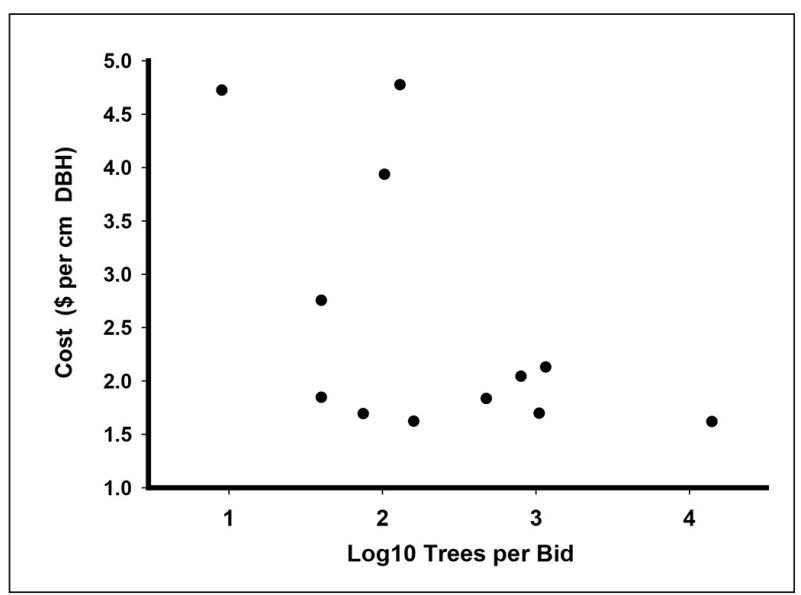

Figure 2. Cost per $2.5 \mathrm{~cm} \mathrm{dbh}$ of bids for treating ash trees with emamectin benzoate and number of trees per bid determined by surveying the public records of 27 cities in Illinois, Indiana, Minnesota, Missouri, and Ohio, U.S., from September to December of 2014. Currency is in \$USD.

\section{Simulated Costs and Benefits of Management Programs}

The highest annual costs for managing ash trees were incurred when trees were removed as they became unsalvageable (reactive removal), followed by proactive removal of ash trees (Figure 4a). Lower annual costs were predicted for treating all the ash trees or trees 


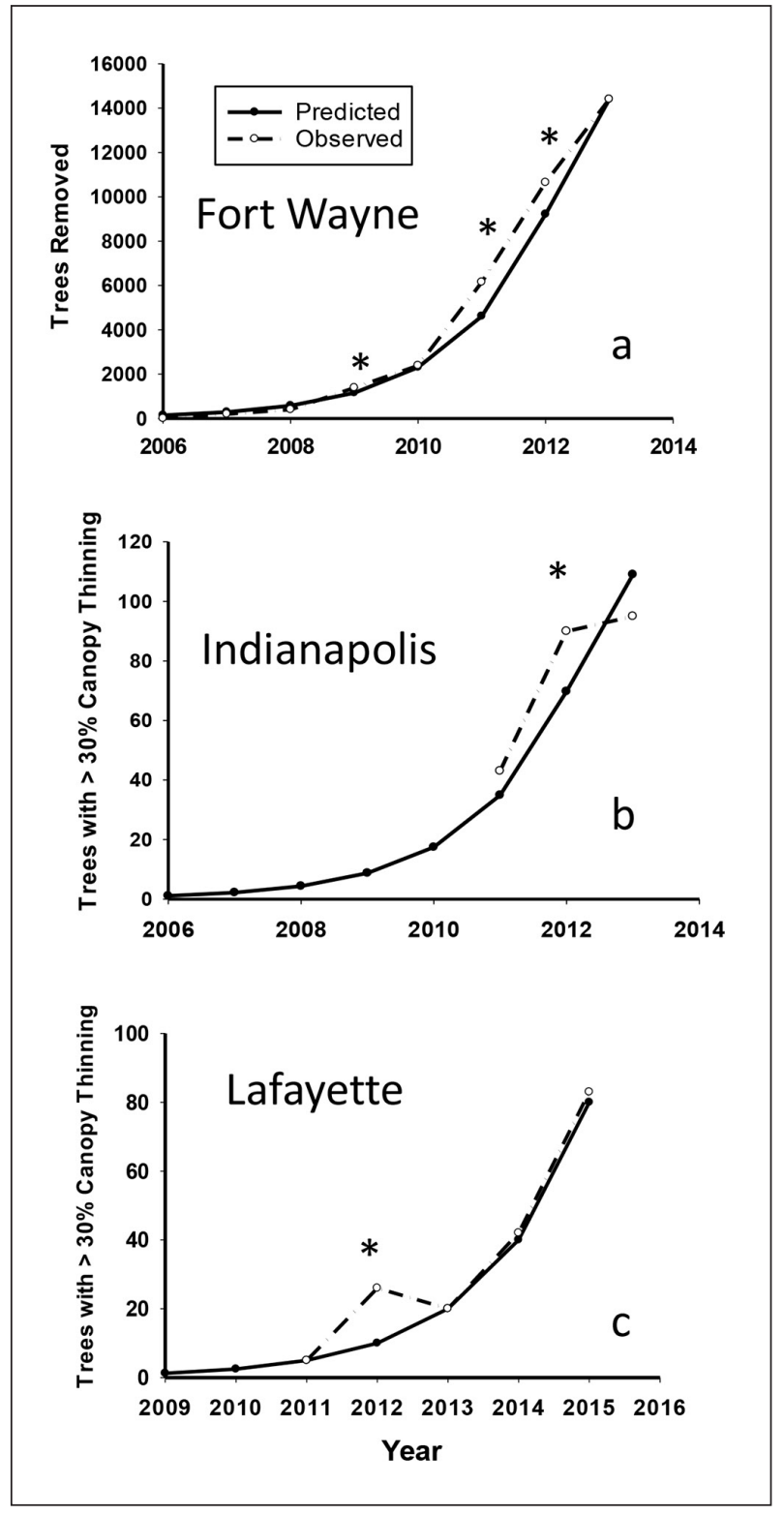

Figure 3. Ash tree decline predicted by the invasion wave model plotted with a) observed rights-of-way tree removals by the City of Fort Wayne, Indiana, U.S., b) numbers of good and fair trees declining to poor quality $(>30 \%$ canopy thinning) in Indianapolis, Indiana, and c) Lafayette, Indiana. An asterisk $(*)$ indicates years with significant difference from the predicted distribution $(P<0.05)$ with a Kolmogorov Smirnov test.

with a dbh $>30 \mathrm{~cm}$. Delaying the implementation of a management strategy to Year 5 of the cycle (Figure 4b) compressed the costs of tree removal and replacement, resulting in substantially higher peak annual costs for proactively (107.8\%) and reactively (39.4\%) removing and replacing trees. Delaying the management strategies caused less of an increase $(16.0 \%)$ for the peak annual cost of treating all trees with a $\mathrm{dbh}>30 \mathrm{~cm}$ because fewer tree removals and replacements were compressed into the remaining years of the ash-decline wave.

After 25 years, the projected size of forests whose ash trees were removed and replaced were less than one-third the size of those whose ash trees were treated early (Figure $5 \mathrm{a}$ ) or late (Figure 5b) in the wave of ash tree decline. Ratios of total discounted costs to total discounted tree diameters were also greatly lower in management strategies that saved trees (Table $4)$. When the cost of treating an ash tree was $\$ 3.94 / \mathrm{cm}$, the cost-benefit ratios of protecting most ash trees was roughly half of those from proactively removing and replacing all ash trees. Cutting the price of treatment in half

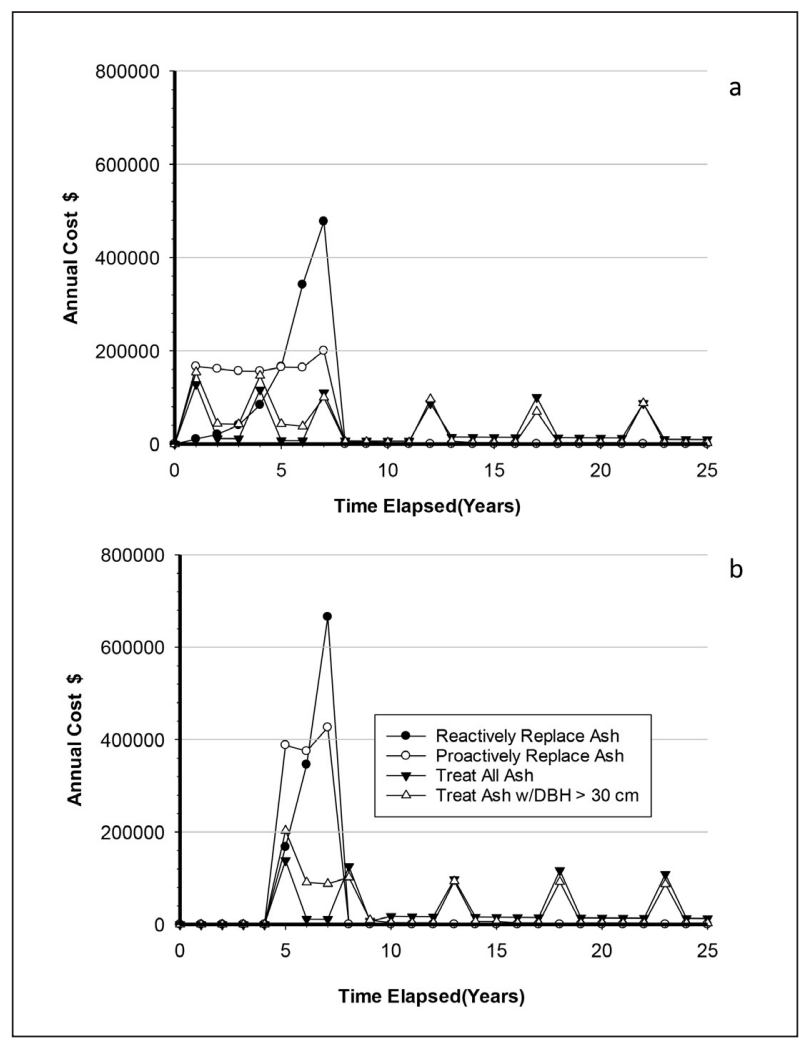

Figure 4. Annual costs of implementing selected management programs of a 1,600 ash tree forest predicted by the EAB Cost Calculator 3.0 when initiated in the a) first year of the invasion cycle ( $1 \%$ of ash trees beyond saving) and $b$ ) fifth year of the invasion cycle ( $16 \%$ of ash trees beyond saving). Cost of treatment assumes a bulk price for emamectin benzoate of $\$ 1.94 / \mathrm{cm}$, and default calculator values for the cost of tree removal and replacement based on Indianapolis estimates. Currency is in \$USD. 
$(\$ 1.97 / \mathrm{cm})$ reduced the cost-benefit ratios of protecting most ash trees by over two-thirds. However, delaying the implementation of management strategies to Year 5 of the ash-decline cycle had little effect on the cost-benefit ratios for strategies requiring treatment. These delays reduced the cost-benefit ratio by $<5 \%$.



Figure 5. Tree growth (total dbh) of 1,600 ash forests managed under selected regimes predicted by the EAB Cost Calculator 3.0 when initiated in the a) first year of the invasion cycle ( $1 \%$ of ash trees beyond saving) and b) fifth year of the invasion cycle ( $16 \%$ of ash trees beyond saving).

\section{DISCUSSION}

The investigation of ash decline in the wake of EAB invasion support the model used by the $\mathrm{EAB}$ Cost Calculator to predict decline in urban ash forests during the initial EAB invasion. Although the model over or underestimated tree removals in Fort Wayne $37.5 \%$ of the time, it was accurate in Year 5, when nearly $84 \%$ of ash trees were still standing, and in Year 8, when the last of the untreated ash trees were removed. As such, the model approximated the compression of removal costs in the last three years of the removal cycle in Fort Wayne. Thus, the rate at which the EAB Cost Calculator anticipates the removal of untreated ash trees closely approximates the actual costs incurred by one city with a substantial number ash trees in its urban forest.

In contrast, the model of ash-tree decline accurately predicted when an equal number of ash trees ranked as good and fair had deteriorated to the ranking of poor ( $>30 \%$ canopy thinning) in all years but 2012, when there was an historic drought in Indiana. From an operational perspective, this model gives managers a tool to map their position in time on the ash-decline curve. This focus on the accumulation of ash trees with $>30 \%$ canopy thinning can help municipal foresters gather support for treatment efforts before most of the ash trees become unsalvageable.

Investigations of public responses to pest injury on plants suggest that the public could easily detect $30 \%$ canopy thinning on an individual tree. Consumer surveys show that as little as $10 \%$ defoliation, distortion, or discoloration render plants aesthetically unacceptable to the general public (Sadof and Raupp 1997; Sadof and Sclar 2002). Studies of street trees in particular found that as little as 5\%

Table 4. Ratio of total discounted costs associated with emerald ash borer management per meter of trunk diameter of standing trees after implementing selected emerald ash borer management strategies for 25 years in a 1,600-tree forest. The model assumes a $3 \%$ discount rate and treating ash trees every three years through the crest of the EAB invasion wave and every five years thereafter. Reduction is the decrease in the ratio when the cost of treatment is reduced from $\$ 3.94$ to $\$ 1.97$ per $\mathrm{cm}$ dbh. Currency is in \$USD.

\begin{tabular}{|c|c|c|c|c|c|c|}
\hline \multirow{2}{*}{$\begin{array}{l}\text { Time step of initiation } \\
\text { Cost (\$USD) per } \mathrm{cm} \\
\text { for treatment }\end{array}$} & \multicolumn{3}{|c|}{ Year 1} & \multicolumn{3}{|c|}{ Year 5} \\
\hline & $\$ 3.94$ & $\$ 1.97$ & $\begin{array}{l}\text { Reduction } \\
(\%)\end{array}$ & $\$ 3.94$ & $\$ 1.97$ & $\begin{array}{l}\text { Reduction } \\
(\%)\end{array}$ \\
\hline Reactively replace & $\$ 1,758.28$ & $\$ 1,758.28$ & 0.00 & $\$ 1,933.32$ & $\$ 1,933.32$ & 0.00 \\
\hline Proactively replace & $\$ 2,178.42$ & $\$ 2,178.42$ & 0.00 & $\$ 1,983.20$ & $\$ 1,983.20$ & 0.00 \\
\hline Treat $>30 \mathrm{~cm} \mathrm{dbh}$ & $\$ 973.60$ & $\$ 641.19$ & 34.14 & $\$ 981.56$ & $\$ 625.40$ & 36.28 \\
\hline Treat $50 \%$ & $\$ 1,176.18$ & $\$ 883.30$ & 24.90 & $\$ 1,148.08$ & $\$ 886.33$ & 22.80 \\
\hline Treat $80 \%$ & $\$ 1,050.47$ & $\$ 677.67$ & 35.49 & $\$ 962.17$ & $\$ 648.75$ & 32.57 \\
\hline Treat all & $\$ 1,056.88$ & $\$ 592.97$ & 43.89 & $\$ 952.74$ & $\$ 579.32$ & 39.19 \\
\hline
\end{tabular}


defoliation by orange striped oakworm [Anisota senatoria (J.E. Smith)] (Lepidoptera: Saturniidae) to an individual oak tree was sufficient to trigger a complaint call and a request for pesticide treatment (Coffelt and Schultz 1990). Furthermore, other studies of forest vistas suggest that the general public could discern between forests with as little as $10 \%$ difference in trees with significant canopy dieback (Buyhoff et al. 1992). Thus, it is quite likely that the public will notice the presence of declining ash trees in Year 5 of the eightyear cycle when the model predicts that only $16 \%$ of trees would have been rendered unsalvageable.

It is very difficult to gain support for managing new invasive insects, like $\mathrm{EAB}$, in urban forests, despite effective and proven treatment options. Indeed, the examination of news coverage of municipal responses to $\mathrm{EAB}$ indicates that nearly four of five cities elected to remove all their ash or save less than half of the healthy ash trees. This low rate of ash protection may in part be explained by a failure to adequately communicate the risks EAB bring to a community in the absence of a treatment program. This has been the case for gypsy moth (Lymantria dispar), where public opposition to area wide management approaches can stem from an inability to communicate risks and benefits of managing this serious forest defoliator (Nealis 2009; Tobin et al. 2012; Bigsby et al. 2014). The current study's procedure for estimating the decline of good and fair ash trees could be used with the ash-decline model described herein to communicate current and future risk of ash tree destruction in a local community. When used with the $\mathrm{EAB}$ Cost Calculator, this information can inform discussions early in the invasion process while there is still time to save healthy ash trees.

From a safety perspective, tracking the decline of good and fair ash trees to the poor level focuses attention on ash trees as they become more likely to lose limbs. Recent demographic studies of ash trees in EAB-infested areas indicate that ash trees reach $30 \%$ canopy thinning before they become hazard trees and this measure of decline is a good predictor of EAB presence (Hughes et al. 2015; Persad and Tobin 2015). Thus, framing management objectives in terms of reducing the accumulation of poor ash can also prevent hazards associated with failure of ash tree in rights-of-way and other public spaces.

The current survey of public ash treatment records indicate that cities could substantially lower the treatment price paid per dbh of ash by pooling their efforts to treat more trees. Simulations run with the EAB Cost Calculator suggest that lowering treatment costs reduces both annual and total discounted costs of plans focusing on saving ash trees. These findings are consistent with others (Kovacs et al. 2014) that go so far as to suggest that municipalities consider crossing political boundaries to benefit from economies of scale.

It is not surprising that after 25 years, the management plans that save all ash trees produce substantially larger forests than those that remove and replace all. Cost-benefit ratios associated with protecting ash trees from $\mathrm{EAB}$ in these forests can be over two-thirds lower than for proactively removing and replacing ash trees. These advantages are not likely to be lost if treatment is delayed to Year 5 of the eight-year progression of ash decline, and results in $<5 \%$ increase in the cost-benefit ratio. Thus, the results of the current study support the findings of others that show saving ash trees is more cost-effective than removing and replacing them (McCullough and Mercader 2012; Vannatta et al. 2012; Kovacs et al. 2014). Moreover, even several years after the initial EAB invasion, there are enough healthy ash to retain advantages of an intervention program (EpanchinNiell and Wilen 2012). Economic advantages of protecting ash trees can only increase as areawide approaches are developed that lower costs of protection by treating only a fraction of the urban ash trees (McCullough and Mercader 2012).

In conclusion, in the absence of pesticide treatment, the arrival of EAB into an urban forest will destroy ash trees in a predictable manner that can be described by an eight-year model of ash decline. Municipal foresters can stage the level of EAB infestation by monitoring a subsample of trees, ranked as good and fair, and then use the model to inform management decisions. This information, along with a local tree inventory and cost estimates, can be used with the EAB Cost Calculator to help convince communities of the advantages of treating ash trees to save them from a destructive pest. 
Acknowledgments. We thank C. Tinkel, City Forester for sharing Fort Wayne removal data, B. Shaw, B. Kiger, A. Mertz, P. Pinco, and D. Mindham for providing survey trees in West Lafayette, Lafayette, Indianapolis, and Carmel, Indiana. We also want to thank B. Blood, G. Frazier, M. Paschen, L. Patrick, J. Prado, A. Rios, C. Quesada, S. Stack, K. Strack, T. Stewart, N. VanDerLann, and C. Wood for assisting in surveys, B. Delara, and R. Moore for programming the updated calculator, and $\mathrm{E}$. Imboden for computer logistical support. We are also thankful to R. Haight of USFS for reviewing this paper and his suggestions for the economic analysis. This project was funded by USDA-NIFA-41530-21043 awarded to MDG and CSS.

\section{LITERATURE CITED}

Anulewicz, A.C., D.G. McCullough, and D.L. Cappaert. 2007. Emerald ash borer (Agrilus planipennis) density and canopy dieback in three North American ash species. Arboriculture \& Urban Forestry 33:338-349.

Ball, J., S. Mason, A. Kiesz, D. McCormick, and C. Brown. 2007. Assessing the hazard of emerald ash borer and other exotic stressors to community forests. Arboriculture \& Urban Forestry 33:350-359.

Bigsby, K.M., M.J. Ambrose, P.C. Tobin, and E.O. Sills. 2014. The cost of gypsy moth sex in the city. Urban Forestry \& Urban Greening 13:459-468.

Burr, S.J., and D.G. McCullough. 2014. Condition of green ash (Fraxinus pennsylvanica) overstory and regeneration at three stages of the emerald ash borer invasion wave. Canadian Journal of Forest Research 44:768-776.

Buyhoff, G.J., J.D. Wellman, and W.A. Leuschner. 1982. Estimating psychological disutility from damaged forest stands. Forest Science 24:424-432.

Cappaert, D., D.G. McCullough, T. Poland, and N. Siegert. 2005. Emerald ash borer in North America: A research and regulatory challenge. American Entomologist 51:152-165.

Chen, Y., M.D. Ulyshen, and T.M. Poland. 2012. Differential utilization of ash phloem by emerald ash borer larvae: Ash species and larval stage effects. Agriculture \& Forest Entomology 14:324-330.

Coffelt, M.A., and P.B. Schultz. 1990. Development of an aesthetic injury level to decrease pesticide use against orange-striped oakworm (Lepidoptera: Saturniidae) in an urban pest management project. Journal of Economic Entomology 83:2044-2049.

Emeraldashborer.info. 2015. Regional Emerald Ash Borer Information Page. Accessed 15 January 2016. <www.emeraldashborer. info>

Epanchin-Niell, R.S., and J.E. Wilen. 2012. Optimal spatial control of biological invasions. Journal of Environmental Economics and Management 63:260-270.

Flower, C.E., J.E. Dalton, K.S. Knight, M. Brickha, and M.A. Gozalez-Meler. 2015. To treat or not to treat: Diminishing effectiveness of emamectin benzoate injections in ash trees heavily infested by emerald ash borer. Urban Forestry \& Urban Greening 14:790-795.

Gotelli, N.J., and A.M. Ellison. 2004. A Primer of Ecological Statistics. Sinauer Associates, Sunderland, Massachusetts, U.S pp. 380-381.

Herms, D.A., and D.G. McCullough. 2014. Emerald ash borer invasions of North America: History, biology, ecology, impacts, and management. Annual Review of Entomology 59:13-30.
Herms, D.A., D.G. McCullough, D.R. Smitley, C.S. Sadof, and W. Cranshaw. 2014. Insecticide Options for Protecting Ash Trees from Emerald Ash Borer, Second Edition. Accessed 04 January 2015. <www.emeraldashborer.info>

Hughes, G., C.S. Sadof, and M.D. Ginzel. 2015. A borer-specific assessment scheme for identifying sentinel trees to delimit invasive borers in urban forests. Arboriculture \& Urban Forestry 41:125-135.

Kovacs, K.F., R.G. Haight, D.G. McCullough, R.J. Mercader, N.W. Siegert, and A.W. Liebhold. 2010. Cost of potential emerald ash borer damage in U.S. communities, 2009-2019. Ecological Economics 69:569-578.

Kovacs, K.F., R.G. Haight, R.J. Mercader, and D.G. McCullough. 2014. A bioeconomic analysis of an emerald ash borer invasion of an urban forest with multiple jurisdictions. Resource and Energy Economics 36:270-289.

Kovacs, K.F., R.J. Mercader, R.G. Haight, N.W. Siegert, and A.W. Liebhold. 2011. The influence of satellite populations of emerald ash borer on projected economic costs in U.S. communities, 2010-2020. Journal of Environmental Management 92:2170-2181.

MacQuarrie, C.J.K., and R. Scharback. 2015. Influence of mortality factors and host resistance on the population dynamics of emerald ash borer (Coleoptera: Buprestidae) in urban forests. Environmental Entomology 44:160-173.

McCullough, D.G., and R.J. Mercader. 2012. Evaluation of potential strategies to slow ash mortality (SLAM) caused by emerald ash borer (Agrilus planipennis): SLAM in an urban forest. International Journal of Pest Management 58:9-23.

McCullough, D.G., R.J. Mercader, and N.W. Siegert. 2015. Developing and integrating tactics to slow ash (Oleaceae) mortality caused by emerald ash borer (Coleoptera: Buprestidae). Canadian Entomologist 147:349-358.

McCullough, D.G., T.M. Poland, A.C. Anulewicz, P. Lewis, and D. Cappaert. 2011. Evaluation of Agrilus planipennis control provided by emamectin benzoate and two neonicotinoid insecticides, one and two seasons after treatment. Journal of Economic Entomology 104:1599-1612.

McKenney, D.W., J.H. Pedlar, D. Yemshanov, D.B. Lyons, K.L. Campbell, and K. Lawrence. 2012. Estimates of the potential cost of emerald ash borer (Agrilus planipennis Fairmaire) in Canadian municipalities. Arboriculture \& Urban Forestry 38:81-91.

McPherson, E.G., J.R. Simpson, P.J. Peper, S.E. Maco, S.L. Gardner, S.K. Cozad, and Q. Xiao. 2006. Midwest Community Tree Guide: Benefits, Costs and Strategic Planting. USDA FS Pacific Southwest Research Station General Technical Report PSWGTR-199. 100 pp.

Nealis, V. 2009. Still invasive after all these years: Keeping gypsy moth out of British Columbia. The Forestry Chronicle 85:593-603.

Peper, P.J., C.P. Alzate, J.W. McNeil, and J. Hashemi. 2014. Allometric equations for urban ash trees in Oakville, Southern Ontario, Canada. Urban Forestry \& Urban Greening 13:174-183.

Persad, A.B., and P.C. Tobin. 2015. Evaluation of ash tree symptoms associated with emerald ash borer infestation in urban forests. Arboriculture \& Urban Forestry 41:103-109.

Poland, T.M., T.M. Ciaramitaro, and D.G. McCullough. 2015. Laboratory evaluation of the toxicity of systemic insecticides to emerald ash borer larvae. Journal of Economic Entomology 109:705-716. 
Raupp, M.J., A.B. Cumming, and E.C. Raupp. 2006. Street tree diversity in eastern North America and its potential for tree loss to exotic borers. Arboriculture \& Urban Forestry 32:297-304.

Rose, D.W., C.R. Blinn, and G.J. Brand. 1988. A Guide to Forestry Investment Analysis. USDA Forest Service, North Central Forest Experiment Station, Research Paper NC-284. St. Paul, Minn. 23 pp.

Sadof, C.S. 2016. Emerald Ash Borer Cost Calculator 3.0. Accessed 18 January 2016. <http://int.entm.purdue.edu/ext/ treecomputer $>$

Sadof, C.S., and C.S. Sclar. 2002. Developing an aesthetic threshold for a public display garden. Journal of Economic Entomology 95:348-353.

Sadof, C.S., and M.J. Raupp 1997. Aesthetic thresholds and their development. In: L.G. Higley and L.P. Pedigo (Eds.). Economic Thresholds for Integrated Pest Management. Univ. Nebraska Press. pp. 203-227.

Sadof, C.S., L. Purcell, F.J. Bishop, C. Quesada, and Z.W. Zhang. 2011. Evaluating restoration capacity and costs of managing the emerald ash borer with a web-based cost calculator in urban forests. Arboriculture \& Urban Forestry 37:74-83.

Smitley, D.R., J.J. Doccola, and D.L. Cox. 2010. Multiple-year protection of ash trees from emerald ash borer with a single trunk injection of emamectin benzoate, and single year protection with an imidacloprid basal drench. Arboriculture \& Urban Forestry 36:206-211.

Sydnor, T.D., M. Baumgardner, and A. Todd. 2007. The potential economic impacts of emerald ash borer (Agrilus planipennis) on Ohio, U.S., communities. Arboriculture \& Urban Forestry 33:48-54.

Sydnor, T.D., M. Bumgardner, and S. Subburayalu. 2011. Community ash densities and economic impact potential of emerald ash borer (Agrilus planipennis) in four midwestern states. Arboriculture \& Urban Forestry 37:84-89.

Tanis, S., and D.G. McCullough. 2012. Differential persistence of blue ash and white ash following emerald ash borer invasion. Canadian Journal of Forest Research 42:1542-1550.

Tanis, S., and D.G. McCullough. 2015. Host resistance of five Fraxinus species to Agrilus planipennis (Coleoptera: Buprestidae) and effects of paclobutrazol and fertilization. Environmental Entomology 44:287-299.

Tluczek, A., D.G. McCullough, and T. Poland. 2011. Influence of host stress on emerald ash borer (Coleoptera: Buprestidae) adult density, development, and distribution in Fraxinus pennsylvanica trees. Environmental Entomology 40:357-366.

Tobin, P.C., B.B. Bai, D.A. Eggen, and D.S. Leonard. 2012. The ecology, geopolitics, and economics of managing Lymantria dispar in the United States. International Journal of Pest Management 58:195-210.

Vannatta, A.R., R.H. Hauer, and N.M. Schuettpelz. 2012. Economic analysis of emerald ash borer (Coleoptera: Buprestidae) management options. Journal of Economic Entomology 105:196-206.

Villari, C., D.A. Herms, J.G.A. Whitehill, D. Cipollini, and P. Bonello. 2016. Progress and gaps in understanding mechanisms of ash tree resistance to emerald ash borer, a model for wood-boring insects that kill angiosperms. New Phytologist 209:63-79.

Wei, X., Y. Wu, R. Reardon, and T.H. Sun. 2007. Biology and damage traits of emerald ash borer (Agrilus planipennis Fairmaire). China Insect Science 14:367-373.
Clifford S. Sadof (corresponding author)

Department of Entomology

Purdue University

West Lafayette, Indiana 47907-2089, U.S.

csadof@purdue.edu

Gabriel P. Hughes

Department of Entomology

Purdue University

West Lafayette, Indiana 47907-2089, U.S.

Adam R. Witte

Department of Entomology

Purdue University

West Lafayette, Indiana 47907-2089, U.S.

Donnie J. Peterson

Department of Entomology

Purdue University

West Lafayette, Indiana 47907-2089, U.S.

Matthew D. Ginzel

Department of Entomology

Purdue University

West Lafayette, Indiana 47907-2089, U.S. 
Résumé. Les progrès en matière de contrôle peuvent aider les arboriculteurs municipaux à sauver les frênes de l'agrile du frêne (Agrilus planipennis [Fairmaire]) dans les forêts urbaines. Bien que les frênes de toutes dimensions peuvent être protégés contre ce ravageur, les villes mettent rarement en place des programmes parce qu'elles ne reconnaissent pas l'urgence d'agir sur les populations naissantes de l'agrile. Dans cette étude, les chercheurs ont élaboré un modèle pour prédire la mortalité des frênes sur une période de huit ans, modèle validé par des données provenant de l'abattage de plus de 14000 frênes tués par l'agrile à Fort Wayne en Indiana, États-Unis. Les chercheurs ont par la suite développé un procédé d'échantillonnage afin d'aider les forestiers urbains à dresser la cartographie de leurs frênes en considérant la progression anticipée de leur déclin. Ce modèle a alors été utilisé pour modifier un calculateur en ligne des coûts liés à l'agrile, comparant les coûts actualisés annuels et cumulatifs de mise en œuvre d'une variété de stratégies de gestion. Il a été déterminé que les stratégies qui misaient le plus fortement sur la sauvegarde des frênes étaient moins onéreuses et produisaient des arbres plus gros que les stratégies qui se contentaient surtout d'abattre et de remplacer les frênes. Les ratios des coûts totaux actualisés par rapport aux avantages cumulatifs actualisés des stratégies qui sauvegardaient la plupart des frênes étaient inférieurs de plus des deux tiers par rapport aux stratégies proactives d'élimination et de remplacement des arbres. Le fait de retarder la mise en œuvre d'un programme de gestion des frênes jusqu'à ce que les dégâts soient visibles et plus évidents par la communauté (année 5 du modèle) a diminué le rapport coût-bénéfice de $5 \%$. Par conséquent, les délais qui se fondent sur l'abondance d'arbres endommagés localement pour recevoir le soutien des communautés ne diminuent pas nécessairement l'utilité implanter une stratégie de contrôle.

Zusammenfassung. Fortschritte bei der Kontrolle können kommunalen Förstern helfen, die Eschen in urbanen Wäldern vor dem Befall mit dem Eschenbohrer (EAB) zu retten. Obwohl Eschen jeder Größe vor diesem Schädling geschützt werden können, haben Städte oft keine Programme implementiert, weil sie nicht in der Lage sind, die beginnende Käferpopulationen von EAB zu erkennen und zu handeln. In dieser Studie entwickeln Forscher ein Modul zur Vorhersage von Eschen-Mortalität über eine Periode von acht Jahren, welches durch die Daten aus der Beseitigung von > 14.000 abgestorbenen Eschen in Fort Wayne, Indiana, U.S. validiert wurde. Die Forscher entwickelten dann ein Probennahmesystem, um Förstern zu helfen, ihre Eschen entlang der erwarteten Progression des Eschenrückgangs zu kartieren. Dieses Modell wurde dann verwendet, ein web-basiertes EAB-Kosten-Kalkulationsprogramm zu modifizieren, welches die herabgesetzten jährlichen und die kumulativen Kosten der Implementierung einer Auswahl von Managementstrategien miteinander vergleicht. Es war bestimmt, dass die Strategien, welche stark auf der Rettung von Eschen basieren, weniger Kosten und größere Waldflächen produzieren als solche Strategien, die hauptsächlich befallene Eschen entfernen und ersetzen. Die Verhältnisse der totalen diskontierten Kosten zu den diskontierten kumulativen Vorteilen derjenigen Strategien die die meisten Eschen retteten, waren über zwei Drittel niedriger als Strategien zur proaktiven Eschenbeseitigung und Ersatzpflanzung. Eine verzögerte Implementierung eines Eschen-Managementprogramms erst bei der ersten Sichtbarwerdung von Schäden und damit deutlicher erkennbar für die Kommune (Jahr 5 des Modellversuchs) verringerte das Kosten-Nutzen-Verhältnis um $<5 \%$. Daher können Verzögerungen, die zunächst ein Massenaufkommen von geschädigten Bäumen brauchen, um eine Unterstützung in der Kommune zu erhalten, nicht unbedingt die Nützlichkeit der Implementierung solcher Programme geringer werden lassen. 